\title{
Knowledge of public health challenge of open defecation in rural areas of South-East Nigeria: Implications for social workers
}

\author{
Samuel O. Ebimgbo ${ }^{1}$, Chinyere E. Onalu ${ }^{1}$, Ngozi E. Chukwu1, \\ Onyeyilichukwu P. Onwuama ${ }^{2}$, Paulinus S. Okah', Tochi E. Iwuagwu ${ }^{3}$ \\ ${ }^{1}$ Department of Social Work, University of Nigeria, Nsukka \\ ${ }^{2}$ Department of Sociology and Anthropology, University of Nigeria, Nsukka \\ ${ }^{3}$ Department of Human Kinetics and Health Education, University of Nigeria, Nsukka \\ Email: ngozi.chukwu@unn.edu.ng
}

\begin{abstract}
Background: Practice of open defection has growing health concerns especially on rural dwellers and is among leading causes of diarrhea, typhoid fever, cholera, stunting and responsible for the death of children under 5 years in Nigeria. This study seeks to examine knowledge of public health challenges of open defecation among rural residents in south-east Nigeria and implications for social work.

Data source and methods: Focus group discussions and in-depth interviews were used for data collected from 52 respondents in Nsukka and Udenu LGAs of Enugu State. Thematic analysis was adopted and phrases with contextual connotations were pulled as illustrative quotes.

Results: Lack of toilet facilities makes community members engage in the practice despite knowledge of its public health implications.

Conclusions: The study recommends strengthening of government's efforts to eradicate the practice; incorporating social workers as facilitators in public health regulations and advocacy in sensitising households to provide their own toilets.
\end{abstract}

Keywords: Knowledge, open defecation, public health, rural areas, social work

\section{Introduction}

The practice of open defecation is a public health issue which affects both developed and developing countries across the globe; although it is more prevalent in developing nations such as Nigeria (Ngwu, 2017). It is estimated that about 2.4 billion people all over the world do not have access to basic sanitation facilities such as toilets or latrines (World Health Organisation [WHO], 2016). According to WHO (20I4) the practice of open defecation affects the health of almost I billion individuals worldwide and is equally responsible for about 842,000 deaths annually consequent upon sanitation-related diseases. While the report of United Nations Children's Fund [UNICEF] and WHO (2017) revealed that between 1990 and 2015 the proportion of people that defecate in open spaces across the globe seem to have declined from $26 \%$ to $12 \%$, about 892 million people still defecate openly in street gutters, forests, fields, behind bushes or into open bodies of water.

Studies have shown that these unsanitary practices usually take place in rural areas of low-income countries (Coffey et al., 2014; Galan et al., 2013; Geetha and Kumar, 20I4; WHO/UNICEF, 20I5). For instance, in Africa, about 233 million people still lack access to decent toilet facilities hence likely to defecate in open spaces (Ayitey, 2016; WHO/UNICEF, 2016). This practice of open defecation is a major risk factor for under-five mortality in some African countries like Kenya, Uganda, Tanzania (Rutaremwa, 20/2). In Nigeria, the 2016 World Development Indicators revealed that open defecation practice has increased from $24 \%$ of the total population in 1990 to $25.1 \%$ in 2015 (World Bank, 2016). To buttress this point, the report of This Day Newspaper (2016) revealed that Nigeria indeed is one huge field, where people defecate without shame and without taking into consideration the impact of their actions on the health of others. Currently, the report of UNICEF shows that 46.5 million Nigerians still defecate in the open making Nigeria the second highest ranked country in the world (UNICEF, 20I8).

Consequent upon Nigeria's poor sanitation practices, the country loses about 455 billion annually or about $1.3 \%$ of its Gross Domestic Product [GDP], in addition to public exposure to or proliferation of acute excreta-related illnesses especially in children (Water Sanitation Programme, 20I2). Some of these excreta-related (communicable and tropical) diseases include cholera, diarrhea, 
dysentery, hepatitis A, typhoid, polio, intestinal worms, schistosomiasis, and trachoma. Open defecation also accounts for stunting and mortality in children (Mara, 20I7; Hulland et al., 20I5; Spears et al, 2013; WHO; 20I6). The World Bank Report (20I2) shows that approximately 121,800 Nigerians, including 87,000 children below five years die annually from diarrhea; while nearly $90 \%$ is as a result of poor sanitation and hygiene. From this report, Nigeria remains a major contributor to global statistics on under-five mortality (Adenini, 20/4). According to Ngwu (2017) this barbaric practice does not only kill babies but equally impedes the physical and cognitive development of surviving children. It also has significant negative externalities and releases germs into the environment which pose serious harm to both the rich and the poor in the society.

Open defecation was found by scholars to be a substantial threat not only to environmental and human health, safety and privacy but also to the dignity of women and children in the society (Abubakar, 2017, Desai et al., 2015; Giné-Garriga et al., 2017). The report by WaterAid (2013) reveals that open defecation is one of the social stigmas currently affecting Nigerian women. For instance, the Federal Ministry of Water Resources (2016) stated that it is out of place to watch helpless young girls and women who squat in order to remove excreta. Also, the dignity and worth of women and girls are reduced for dearth of adequate toilet facilities at home; for this reason, women have to delay till sunset or early hours to relieve themselves lest they be seen by others. This form of violence against women (married and unmarried) in rural areas is one of the social evils that has been prevailing in recent years. As women are mostly at risk and their dignity not only affected, their safety is equally at risk because by resorting to bush areas or farm land, dark or hidden places to defecate, many women to a great extent are vulnerable to rape and other forms of sexual assault (Ngwu, 2017). In the same vein, the unwholesome practice affects women's genitourinary tract which is one of the risk factors to miscarriage and stillbirth (Tarraf, 20I6).

In view of the above, social workers are required to play important roles in order to ensure that the wellbeing of the rural populace is addressed through provision of adequate toilet facilities as well as information on health challenges associated with open defecation. According to International Association of Schools of Social Work [IASSW] and International Federation of Social Work [IFSW] (20I4), social workers promote social change and development, social cohesion, and the empowerment and liberation of people; they also engage people and structures to address life challenges and enhance wellbeing. Social workers usually achieve these feats through resource linkage/mobilisation, public enlightenment campaign and advocacy.

According to Sheafor and Horejsi (2006), social workers facilitate linkage between individuals and available resources in the society. These resources could be gaining access to social provisions such as decent toilet facilities. Thus, social workers link rural dwellers to agencies like non-governmental organisations [NGOs], the private sector, social clubs among others that can provide them with toilet facilities. In the same vein, social workers through advocacy, influence formulation and implementation of policies that aim at ameliorating the practices of open defecation through provision of adequate toilet facilities. Zastrow (2004) avers that one of the roles of social work is to always advocate for policies and programmes that address the provision of social services especially to the poor. Social workers also disseminate relevant information regarding public health challenges associated with open defecation. This is usually carried out through effective public enlightenment campaign among the rural populace. According to Madumere (2017), public enlightenment usually appeals to the emotions of people and raise their consciousness regarding the consequences of some of their actions, thereby stimulating their change of behaviours in more positive manner.

In view of the foregoing, the quest for African countries to achieve global health development and be amongst the best performers in global quality of life measures by 2063 has been foremost in the African Union Agenda. This should be achieved through the provision of basic services such as health, water and sanitation. Drawing from this backdrop, this study examines the knowledge of public health challenge of open defecation in rural areas of southeast Nigeria; while addressing the implications of findings to social workers in Nigeria.

\section{Literature review and theoretical framework}

There has been documented efforts of urban planners, health practitioners, environmentalists and international development agencies such as $\mathrm{WHO}$ and UNICEF with regard to curbing the practice of open defecation across the globe (Desai et al., 2015; Galan et al., 2013; Gertler et al., 2015; WHO/UNICEF, 20I5). However, there are some notable factors that encourage the practice of open defecation across the globe. According to Ahmad (2014) the practice of open defecation is associated with cultural and religious beliefs of some people. For instance, Alhassan and Anyarayor (2018) revealed that some cultures do not regard open defecation as 
a serious concern but a way of maintaining their fore fathers' practice and ancestral links. In the same vein, Newman et al. (20l4) aver that some cultures perceive a father-in-law sharing the same toilet facilities with daughter-in-law in the same household as a taboo. Coffey et al. (2017) equally found that in India, Hindus compared to Muslim Indians are more prone to open defecation. Thus, owning private latrine is considered ritually polluting and offensive as most Indians build altars for their gods in their homes, so building a latrine in the same household is considered unclean and insulting to the gods.

According to WHO/UNICEF (2014) report, most countries where open defecation is widely practised have high levels of poverty. Therefore, economic status of people is one crucial factor that encourages people to defecate in open places (Routray et al., 2015; UNICEF, 20I5). According to Kamal and Chambers (2008), households that are high in economic status usually construct modern toilet facilities in their respective homes as measures against some transmittable diseases occasioned by open defecation, a feat which poor households could not achieve. Also, Akter and Ali (2003) aver that in Bangladesh, lack of income encouraged the populace to defecate in open spaces. Poor individuals because of their low financial positions are unable to own private toilet in their households, resulting in shared latrine or defecation in the open. Equally, in a study by Okafor and Nwude (2015) on hygiene and sanitation practices of coastal communities, findings revealed that level of income is a crucial factor that affects open defecation. The study therefore concluded that people with low income are more likely to defecate in open spaces than people with high income.

Regarding gender and the practice of open defecation, Miner et al (2017) found that in Jos, Nigeria, men resort to open defecation more than females because of the stigma females face when they are found defecating outside. In the same vein, Routray et al. (2015) discovered that in India, males defecate in open spaces more than females because females require somewhere safe and convenient in order not to be caught. Similarly, Coffey et al. (2014) revealed that even in the presence of wellconstructed latrines in the households, men are more likely than women to defecate in open spaces. Furthermore, Bhardwaj et al. (20I3) found that more women than men found open air defecation even more embarrassing and dangerous thereby refraining from such practices. Concerning age, Coffey et al (2014) noted that open defecation increases with age because older people, on average, are able to move more freely outside their homes and to enact their preferences. This is because they were born into earlier years when the practice of open defecation was more common than it is today.

Furthermore, some scholars have unearthed some factors that influence the knowledge of public health challenges of open defecation. For instance, Routray et al (2015) found that age, lack of education and low economic status lead to poor knowledge of health consequences of open defecation. According to them, younger people are more likely to have knowledge of public health challenges of open defecation than older people. In the same vein, lack of education results in ignorance which hinders knowledge of public health consequences of open defecation. It is predominant among the poor folks who cannot afford formal education and hence, see no reason why they should adopt or own a private toilet in their households. In the view of Okullo et al. (2017), poor knowledge of public health problems of open defecation is as a result of ignorance caused by lack of education among the locals. Also, Akinson (2016) revealed that ignorance due to lack of education concerning the health hazards of open defecation has led to more people in rural areas in which large percentage of their population cannot afford formal education to practice open defecation. According to Tarraf (2016), education is a positive instrument of change in order to combat sanitation problems especially where open defecation practice is high. He further revealed that in communities that still practise open defecation, the educated population is found less likely to indulge in it due to knowledge of both the health and environmental problems.

Empowerment theory was adopted to provide the framework analysis for this study. The empowerment theory was developed by Solomon (1976). Other theorists such as Mallucion and Libassi (1984); Guiterrez, Dubois and Maye (1995); and Miley, O' Melia and Dubois (200I) made significant contributions in shaping the theory. Empowerment is the ability of individuals to gain control socially, politically, economically, and psychologically through access to information, knowledge and skills; decision making; and individuals self-efficacy, community participation and perceived control (Zimmerman \& Rappaport, 1988). As a process, empowerment helps individuals and groups gain power, access resources and gain control over their lives. It enables people to develop the ability to achieve their highest personal and collective aspirations and goals (Robins et al., 1988). Empowerment theory provides an effective support system for individuals, groups and communities that have been blocked from achieving collective goals. Payne (2005) asserts that empowerment practice helps individuals and groups 
to overcome social barriers and self-fulfillment within existing structures.

Empowerment theory helps to explain why majority of rural dwellers are still defecating in open spaces despite having the knowledge of associated health outcomes. This to a large extent might be influenced by the gap in formal education and access to decent toilet facilities. As empowerment entails the process of helping individuals and groups gain power, access resources and gain control over their lives and also enables people to gain the ability to achieve their highest personal and collective aspirations and goals; most of these rural dwellers need to be empowered through formal education in order to enable them gain perceptive control to desist from open defecation practices. Secondly, these rural dwellers are plagued with many lifethreatening diseases as a result of open defecation practices which could factor around dearth of toilet facilities. Thus, if these rural dwellers are provided (empowered) with some resources (toilet facilities) by the government or non-governmental agencies, it will enable them to pursue their personal and collective goal which is to maintain perfect health condition.

\section{Data and methods}

This study was conducted in rural areas of Nsukka and Udenu LGAs, Enugu State South-East, Nigeria. Enugu state was created in August 27, 1991 with Enugu city as its capital and has a population of $3,267,837$ comprising of 1,596,042 males and I,67I,795 females. Nsukka and Udenu LGAs have a population of 309,448 and 178,687 respectively (National Population Commission (NPC), 2006). The choice of adopting rural areas in Enugu state was informed by the fact that Enugu State ranks first in the south-east and 9th among the States that show higher than the national average (37\%) with regard to open defecation practices. According to records, $30.09 \%$ of Enugu state residents use nearby bush/beach/field as toilet facility (Nigeria Data Portal, 2015). Also, rural residences were selected because in urban areas the most popular toilet facility used are flush to septic tank or to a pit while in rural areas open defecation is more in vogue.

Cross-sectional design using qualitative instruments of Focus Group Discussion [FGD] and In-depth Interview [IDI] guides was adopted for the study. Probability and non-probability sampling procedure was adopted to select participants for the study. The sample of 52 participants comprising 32 respondents from Nsukka LGA and 20 respondents from Udenu LGA was selected for this study. Two rural communities were randomly selected by balloting from Nsukka LGA for the FGD; the communities include ọbụkpa and lbagwa-Anị while one community (Agụ-Oba) was purposively selected in Udenu LGA for the IDI. The choice of selecting only Agụ-Oba in Udenu was as a result of high practice of open defecation in the environment. For the FGD, four FGDs were conducted in Nsukka LGA; this comprised 32 participants who were 18 years and above. Two FGDs were conducted in Ọbụka with male participants while another two were conducted in Ibagwa-Anị. In doing so, two villages were randomly selected from each of the communities; the villages include (Obige and OgbaAgụ [ọbụkpa]; Akụma and Amafọ [lbagwa-Anị]). The focus group discussion consists of two all-male groups and two all-female groups with eight participants in each group. The researchers were responsive about age and gender while choosing the participants; hence one group was constituted for younger female participants aged $18-35$ years and another group was constituted for female older participants aged 36 years or older. The same grouping process was followed while constituting male discussion groups.

For the IDI, 20 IDls were conducted in five villages (Mgboroko, Igboneme, Isiugwu, Odenigbo and Leke) in Agụ-Ọba community of Udenu LGA. The respondents for the IDls were male and female who were between the ages of 18 years and above. Four respondents ( 2 males and 2 females) were randomly selected from each of the villages.

The field exercise was carried out between May and June, 2018; the field lasted for four weeks with duration of roughly 55 - 60 minutes for each discussion session and $30-45$ minutes for in-depth interviews. The discussions (FGDs and IDIs) were audio-taped; one of the researchers facilitated the interview and discussion sessions while the other researchers performed the duty of note-taking. The interview schedule and FGD guide contained unstructured questions in order to stimulate more probing on the issue under study. The analyses of the transcripts and field notes were performed according to the inductive thematic analysis (Braun and Clarke 2006). The generated data were initially transcribed in Igbo language and translated verbatim into English language. This was to make certain that transcription in both languages has same meaning. The researchers independently read and re-read the analysis of transcripts in order to familiarise themselves with the analyzed data. As the researchers were going through the analysis of transcripts, some common and recurrent themes were identified. Upon these identified common and recurrent themes the final findings of this study were reported. 
Ethical considerations

The Ethical Review Board of the University of Nigeria, Nsukka approved the study instrument and methodology; meanwhile oral informed consent was sought and obtained from each participant before they were recruited for this study.

\section{Results}

\section{Demographic characteristics}

The demographic characteristics of the respondents were analysed as shown on the Table I below. The analysis on the table indicates there is equal percentage in the gender and age of the respondents. The analysis of the study equally indicates that majority of the respondents $(63.5 \%)$ were married; this was followed by $25 \%$ percent of the respondents who were single as at the time of this study. Only $7.7 \%$ were widowed while $3.8 \%$ were divorced. Regarding the level of education of the respondents, the analysis shows that the highest proportion of the respondents $(44.2 \%)$ had no formal education while $32.7 \%$ and $17.3 \%$ of the respondents had primary and secondary education respectively; only $5.8 \%$ had tertiary education. This result may not be misleading because this study was conducted in rural areas where rate of education is relatively low. The findings also indicate that $50 \%$ of the respondents were farmers followed by $26.9 \%$ who were students; $9.6 \%$ were self-employed while $1.9 \%$ were formally employed. The analysis shows that $5.8 \%$ of the respondents were civil servants and $5.8 \%$ were unemployed.

Table I: Socio-demographic characteristics of respondents

\begin{tabular}{lll}
\hline Demographic data & Frequency & Percentage \\
\hline Sex & & \\
Male & 26 & 50 \\
Female & 26 & 50 \\
Age & 26 & 50 \\
I8-35 & 26 & 50 \\
$>36$ & & \\
Marital status & 33 & 63.5 \\
Married & 4 & 7.7 \\
Widowed & 13 & 25 \\
Single & 2 & 3.8 \\
Divorced & & \\
Education & 23 & 44.2 \\
None & 17 & 32.7 \\
Primary & 9 & 17.3 \\
Secondary & 3 & 5.8 \\
Tertiary & & \\
Occupation & 3 & 5.8 \\
None & 14 & 26.9 \\
Students & 26 & 50 \\
Farmer & 1 & 1.9 \\
Former employed & 5 & 9.6 \\
Self employed & 3 & 5.8 \\
Civil servant & &
\end{tabular}

Source: Fieldwork 2018

Views on open defecation practices in the rural areas

The researchers probed to find out if there were practices of open defecation in the communities. From the analysis of the transcript, it was discovered that the rural communities indulge in the practice of open defecation. All the participants indicated that open defecation is still in practice in their respective communities. Some of the participants indicated that they defecate in their farmlands while others stated that they defecate in the bush. A male participant in 479! an FGD with younger respondents at obukpa community indicated, "Sometimes we prefer going to bush to defecate". Equally, an older male respondent in an IDI conducted at Agụ-Oba said "I'm aware of open defecation in this community, we usually go to the bush or farm to ease ourselves". Another older participant in an FGD conducted at Ibagwa-Anị community stated, "very well, for me, I like going into the bush to defecate because sometimes pit toilet will be filled with foul odour; you don't have any other choice but to defecate in the bush". Some of the http://aps.journals.ac.za 
respondents' views regarding practice of open defecation are reflected in the following quotes:

Some people in this community usually defecate in the open places either in the streams, bushes or farm lands; I wouldn't say it is a normal thing but people actually do it because they feel confident and comfortable when they defecate in open places rather than making use of the constructed toilet. In this community, some persons use the bush method even when they have constructed toilets inside their houses, they still prefer going outside to defecate. (A younger male participant in FDG at obuikpa).

Supporting the view expressed above, an older female participant in an IDI conducted at Ibagwa-Anị reflected:

Open defecation, that is people who leave their pit toilet to enter bush to defecate. Days ago, someone came at the back of my house and defecated there, the stench from it was too much. It is not good at all.

Another younger male participant at obukpa community stated:

You mean to "shit" (defecate) in the bush, yes, I do it, it is good to go to bush when you are press; in my opinion, it is more often to get infected when using constructed toilet but going to bush, it is good, no infection can be gotten in the bush.

\section{Level of occurrence of open defecation}

The researchers tried to find out the level of occurrence of open defecation practice in the rural areas of south-east Nigeria. This question was necessary consequent upon prior responses of the participants which indicated that rural dwellers practice open defecation. The analysis of the transcript revealed that despite having traces of open defecation practices in the communities, there were some variations in the level of occurrence in these communities regarding the practice of open defecation. For instance, an older female participant in obụkpa community stated that "open defecation is not that regular in this community". In the same vein, a younger male participant in FGD conducted at obukpa said: "nowadays, people still go to bushes to defecate especially those that don't have toilet but it is not much". Another participant in FGD conducted with younger female at Ibagwa-Anị reflected, "yes, we still practice open defecation but it is gradually reducing; nowadays new houses are built and people are now having their own toilets". Another older female participant in Ibagwa-Anị stated: "in this community, people still defecate in the open places but it's not that much. People who don't have money usually go to bush to defecate and people who have money dig pit toilet and construct water cistern".
Other views of the participants are reflected in the following quotes:

Yes, we still practice open defecation in our community but you know things are changing; although some people still practice it even now. People defecate in hidden places and can defecate anywhere. Again, people will finish building houses but will not build toilet inside but will build it outside, the one called pit toilet; when the pit toilets are filled and not evacuated, they will be attracting flies thereby prompt them to defecate in the open places. (Older female participants in FGD at Ibagwa-Anị).

Another younger male participant in an FGD at ọbụkpa equally reflected:

People in this community though not all of them you know do defecate openly. If you go around this community, you'll see families that have toilets but still go outside to defecate, some of them don't even care. In my own community, there are different are families involved in it, let me say about $25 \%$ of families are involved in this practice. Another view expressed but in a different opinion, an older female older participant in an FGD conducted at ọbụkpa reflected:

Yes, but not all families are involved in the practice, my family members used to go to people's pit toilet or into the bush to defecate when we didn't have our own toilet but we stopped when we built our own toilet. Nowadays, few people are still defecating in the open areas especially those families that don't have pit toilets or don't like using pit toilets to defecate.

Contrary to the practice of open defection in rural areas of Nsukka LGA (Ọbụka and Ibagwa-Anị communities), it was discovered that open defecation is a regular practice in the rural area of Udenu LGA (Agụ-oba community). The finding of the study revealed that all the community members (households) adopt open defecation as toilet measures; it is also a regular practice in the community. An older male respondent in an IDI conducted at Agụ-oba stated, "eeh, it is true that we all go to toilet in the bush always". An older female respondent equally stated, "in this Agụ-Oba, everybody usually defecates in the bush". A younger male respondent indicated, "it is something that we do regular". An older female respondent also reflected thus: "we are into open defection always; we do it in the morning, afternoon, and night". Another older female respondent indicated that "in the community, one person can even defecate twice of thrice a day in the bush". A younger female respondent stated, "we do it almost every day". An older female respondent in an IDI expressed her view in the quote below: 
I usually see many members of this community in the bush defecating because we don't have toilets. I always see them especially those of us living within this environment (Mgboroko) and the neighbouring areas (Isiugwu and lgboneme) whenever they go to bush to defecate.

\section{Knowledge of health challenges of defecating in the open}

Questions were raised to ascertain the level of knowledge of health consequences of open defecation among the rural dwellers. From the responses of the participants, it seems that majority of the respondents are aware of health challenges of open defecation. Only a handful of the participants stated that open defecation has no health challenges. For instance, in obukkpa community, an older male participant in FGD stated thus: "no, open defection has no effect; I don't think it has any health problem". Another older female respondent in an IDI conducted at Agụ-Oba said: "I don't know that one can get infected from defecating in the open; I think it is only from pit toilet that one gets infected". With the exception of these very few participants, majority of the participants indicated that defecating in the open could result to different sicknesses, diseases and infections. Such sickness as noted by the participants include malaria, typhoid, cholera, skin itching, catarrh etc. Other participants equally stated that open defecation may result in snake bite and other physical injury. A male respondent in an IDI stated thus, "there are many health challenges but typhoid and running stomach are most common effect of open defecation". Some of the views of the participants are reflected in the following quotes:

We know there are many health challenges associated with open defecation; the only thing we do is to avoid defecating in a particular spot many times rather when you defecate in a particular area for some days, you have to go to another location in subsequent days to avoid contacting diseases from the earlier defecated ones. (Older female respondent in IDI at AgụOba).

Another older female participant in an FGD conducted in obụkpa stated:

In the olden days when we were given birth, defecating in the open had no health effect; nowadays it can cause some health upset even ordinary pit toilet infects people except the one that can be flushed, although people can be infected through it but it is better than pit toilet that both men and women go, it brings about infection. The health consequences of open defection are many, different diseases because 4793 areas you want to defecate as well. Most time it has foul stench which is capable of affecting people especially girls.

Another older female participant in an FGD at Ibagwa-Anị said:

It has; the more people defecate at places not meant to, the more they are infected. Even stepping into environment where people have defecated can cause people to be infected. Even by breathing in the areas people defecate, you can be infected. Diseases that are contacted through open defecation are many; all these bacteria that causes dysentery, that's running stomach. Sometimes when people defecate in open places, they start having running stomach and they will be told to get drugs. There are many and I can't mention all diseases; they are many.

Another female participant in an FGD in Ibagwa-Anị opined:

It is what causes diseases in someone's health. Like I said, when my relative had running stomach, and typhoid, when took him to hospital, we were told that what brought about it is open defecation. All these mosquitoes, when they perch on the faeces, they will carry it around and when they touch us or our food, it causes running stomach.

A male respondent in an IDI in Agụ-Oba stated:

$E m m$, open defecation can make someone have running stomach. Again, most people who go to bush to defecate don't use toilet tissue, after defecating, they will not clean their anus, thereby, they will start having one disease or the other like itching.

Factors of open defecation among rural populace From the analysis of transcript, it was revealed that rural dwellers still defecate in the open despite some of them knowing the health challenges of the practice. The researchers sought to find out some of the reasons for indulging in the practice despite their wealth of knowledge. The analysis of the transcript revealed that open defecation in the rural areas is attributed to many reasons such as lack of toilet facilities. A younger male respondent in an IDI at Agụ-O ba in his opinion stated: "it is because there are no toilet facilities in our families". Another older female participant at Ibagwa-Anị said: "if I should say, not everybody has access to toilet facilities, so if I don't have toilet, I'll use the bush". An older male participant in an FGD at Ibagwa-Anị equally reflected:

As I have said earlier, when people don't have toilets they will go to bush or farmland to defecate. We do it here, households that don't have money to dig toilets usually go to the bush.

http://aps.journals.ac.za 
Before, we used to defecate in the bush before we were able to dig our latrine few years ago. So, people not having access to toilet causes their defecating in the open.

Going further, the analysis of the transcript revealed that lack of toilet facilities which was one of the causes of open defecation as stated by the participants was consequent upon economic constraints. Great number of the participants indicated that they defecate in the open places because they lack money to put up proper toilet facilities. An older female participant in FGD conducted at obụkpa community stated, "what prompts people to go to bush to defecate is because they don't have money to build toilet inside their house or outside, that's the reason some people go to bush". Another older female respondent in an IDI at Agu-Oba reflected, "the cause of open defecation in this community is lack of finance, some families are not financially okay". Another younger female respondent in IDI conducted at Agụ-ọba said, "what brings about open defecation are many, some families don't have money to build toilets". Also, an older male participant in an FGD at obụkpa reflected his view in this quote:

It is not informed by cultural practices but what made it appears as if it is cultural practice is that some people, because they don't have money to build water system toilet, it made people to go and defecate anywhere they see bush. It is said that when something is repeatedly done it seems to be a culture but it is not.

Another older female participant in an FGD conducted at obụkpa stated that:

What causes open defecation from my own perception is lack of understanding of the negative effect of open defecation. The second one is poverty and lack of money which is also implies that a person might know about the health effect of open defecation but due to lack of money to build toilet, the person will go outside.

Still on factors that encourage open defecation among the rural dwellers, some of the participants noted that some persons defecate openly because they lack formal education, thereby ignoring the necessity of owning toilets. One of the older male participants in an FGD conducted in lbagwa-Anị stated, "lack of education causes open defecation because as you can see, some individuals are not educated to know about the health challenges of open defecation". Another female participant in an FGD conducted at obukpa community revealed that the "leading cause of open defecation is ignorance because people don't know the negative effects of open defecation". A view of an older male participant in an FGD conducted at Ọbukpa reflected thus:

Yes, lack of education is among the reason people defecate in open places. It will be proper that from time to time, community members should be assembled in the town hall and be educated about open defecation and where we should defecate. They should also be educated on health risk. It is good for us to be taught about these so that we can learn.

Another younger male participant in an FGD conducted at lbagwa-Anị reflected:

Education is important to make people to stop defecating in open places because most times, people who do it are ignorant of the problems it brings and as a result, they continue to do it but when people are educated about the problem associated with it, it will deter them from open defecation.

An important finding of this study regarding the enabling factors of open defecation in the rural areas are people's attitudes and perceptions. A younger male participant in an FGD conducted at obụkpa stated: "even when some households managed to build pit latrine; when it gets filled the household may not dig another toilet but prefer going to the bush". Another younger female participant in an FGD in O.bụkpa said, "yes, you see, there are some people who still go to bush to defecate openly even when they dig pit latrines because they think that no one can question them for doing so". An older female participant in an FGD conducted at obụkpa equally stated: "people do what they want and like, sometimes they will tell you that it is none of your business". Some other participants' views are reflected in these quotes:

What causes open defecation is people who finished building houses but didn't build toilet or when someone finishes building toilet and when the toilet gets filled, either to dig elsewhere or empty it, he will leave it and his family members and other people will go to bush to defecate. (older female participant in obu upa).

Still on the attitudes and perceptions as one of the reasons rural dwellers engage in the practice of open defecation, some participants indicated that some individuals resort to open defecation in order to stimulate their smoking lifestyle. One of the male participants in an FGD conducted at obụkpa stated: "people who normally engage in open defecation are those who smoke in my community, most times, they find it comfortable while smoking; while defecating, they enjoy it a lot". Another older male participant in an FGD conducted at Ibagwa-Anị expressed his opinion in this quote: 
Yes, they do it in my community, some people especially young ones do not appreciates going to the erected toilets to defecate. They will always go outside the house where they will express themselves, they can smoke while they are in the bush and also defecate as well, so ehm... they do it a lot.

\section{Discussion}

Open defecation is seen as one of the health challenging practices across the globe which accounts for many deaths in children below five years. This study ascertained the knowledge of health challenges of open defecation in south east Nigeria. From the analysis of the study, several findings were made. The study finding revealed that open defecation is still in practice among rural dwellers. The participants indicated that rural dwellers in the communities studied defecate in open places such as farmlands, bushes, streams etc. This finding is in line with some findings of other scholars like Ngwu (2017) who found that the practice of open defecation is made worse in rural communities in Nigeria where it is tied to the culture, values, tradition and mores of the people. Kamara, Galukande, Maeda, Luboga and Renzaho (2017) revealed that people living in rural areas are less likely to have sanitation facilities. Most of these open defecators are poor and live in rural areas - for example, in India, which had a total of 564 million open defecators in $2015,61 \%$ of the rural population were open defecators vs only $10 \%$ of the urban population (WHO/UNICEF, 20I5).

From the analysis, it was found that there was still high rate of open defecation in the rural communities although there were variations in the level of occurrence in the selected communities regarding practice of open defecation. From the selected communities in Nsukka LGA, some of the households still defecate in open places despite some of them owning their private latrines. A different picture was obtained from the households in the selected community in Udenu LGA who do not have access to toilet facilities thereby resorting to defecating in open places. This implies that the practice of open defecation is still very high among rural dwellers in this study area. This finding is in agreement with the findings of some scholars such as Coffey et al (2014) who stated that there is high rate in the practice of open defecation in rural communities which remains stubbornly widespread with several dire consequences for human health and the environment alike. Also, Abramovsky, Augsburg and Oteiza (2015) found that open defecation practices are more prevalent in rural areas, where $31 \%$ of the population declare to be regular open defecators, whilst this number shrinks to $15 \%$ in urban areas.
Ahmad (2014) indicated that most people in rural communities got to know about open defecation by observing fellow community members. Geetha and Kumar (2014) equally revealed that majority of people practicising open defecation live in rural areas. In rural districts of Tamil Nadu, India, Geetha and Kumar (20l4) found that it was shocking to see that $90 \%$ of the respondents defecate in open places such as the agricultural fields, near the water sources, by the side of thorny bushes and the rest of them in the streets and in open drainages.

Very important to the finding of the study is that majority of the participants were knowledgeable about health challenges of open defecation. Most of the participants indicated that defecating in open places can contribute to cholera, typhoid, catarrh etc. Others noted that open defecation is responsible for snake bites and skin diseases such as itching. This finding is in agreement with the finding of Mumbi and Wilberforce (2017) who found that among residents of Thika East Sub-County, Kiambu County, Kenya, poor child faeces disposal leads to health problems such as Cholera, diarrhea and typhoid in the community. Also, Bhardwaj et al. (20/3) found that in a village of district Pune, Maharashtra, only few of inhabitants were not aware of any harmful effect of open air defecation. On the contrary, Okechukwu et al. (20/2) found that $69.2 \%$ inhabitants of Kintampo of Northern Ghana had either poor knowledge or no knowledge of diseases related to human faeces, at all, the knowledge of which was greatly influenced by educational levels of the populace. In the same vein, Prasad (2013) found that the main reasons for massive practice of open defecation in India with the large sections of the Indian population not convinced of the need to stop open defecation was as a result of lack of proper awareness about the problems associated with open defecation.

Furthermore, the analysis of the transcript revealed that the reason behind rural populace defecating in the open despite their knowledge about the health implications is economic. Majority of the participants indicated that they defecate in open places as result of lack of financial resources to construct their personal toilets. This finding agrees with other findings from several scholars like Geetha and Kurmar (2014) who found that the scenario of availability of latrine facilities in India has improved in the 10 years between $200 \mathrm{I}$ and $20 \mathrm{II}$; but more than half of the nation's households still lack toilet facilities. From as high as 78 per cent of the households without toilet facilities in Jharkhand and Odisha to 2 per cent in Lakshadweep, a large number of people defecate in the open because they cannot afford to build a toilet from their own resources. In the same vein, Banerjee et al (20/3) found that among

http://aps.journals.ac.za 
households of Nandivargam village of Kurnool District, low socio-economic status stimulates openair defecation practice. In Ghana, Arku et al. (2008) found that among rural dwellers, there is a wide discrepancy from the result of the present, and reiterated the fact that money plays a vital role in determining the household owning a toilet or the type of toilet facility in the household.

These findings and assertions have significant implications for social work practice in south-east Nigeria irrespective of its recognition as a young and growing profession in the country. Social work professionals will be of great importance in Nigeria by influencing policies that relate to public health with particular reference to improving sanitation in the 2 Ist century. As professionals that are closer to the rural populace, they will educate community members on the need to adopt good sanitation practices. They will link them to individuals, NonGovernmental Organisations (NGOs), international agencies and government (local, state and federal) resources that would assist them in building communal toilets and helping households who cannot afford modern toilet facilities to dig pit toilets. These measures would discourage all forms of open defecation practices and aid in public health improvement.

Empowerment theory was adopted in this study to structure its framework analysis. Empowerment theory provides an effective support system for individuals, groups and communities that have experienced block from achieving their collective goals and aspiration. Therefore, empowerment practice helps individuals and groups to overcome social barriers and self-fulfillment within existing structures (Payne, 2005). The thrust of empowerment theory conforms to the finding of this study. From the analysis of the study, it was found that majority of the participants attributed defecating in the open places to lack of toilet facilities. The respondents noted that they usually defecate in the bush and farmlands due to the fact that they do not have access to toilet facilities. The inability of these community members to put up toilet facilities in their respective homes according to this study was as a result of lack the money. The finding of the study equally shows that rural dwellers still defecate in the open because they lack formal education. This implies that when rural dwellers are empowered through provision of toilet facilities in various communities, it will to a great extent provide the rural dwellers the opportunities to own their personal toilets. In the same vein, basic education is a form of empowerment to individuals or groups for self fulfilment. Therefore, when rural populace are provided with basic education, they will be self- developed to appreciate the importance of good toilet facilities.

The finding of this study revealed that people's attitudes to a great extent influence their indulgence in defecating in open spaces. It was also revealed that some people despite having good toilet facilities in their homes usually go to the open spaces to defecate. This finding in in conformity with the finding of Devkota (20I I) that poor behavioural attitude (i.e. negligence of proper sanitation habit) is one of the major management related problems for sustainability of eradication of open defecation. Banerjee et al. (2013) equally noted that among rural dwellers construction of toilets has not been considered top priority even when lump sum amount is given to non-toilet resident household. Routray et al, (2015) also aver that in some situations, the effort of the government, NGOs and international agencies in providing toilet facilities may result in futility. This is because providing infrastructure alone does not gurantee its usage especially when there are culturally engrained behavioural barriers, attitudes and practices as well as inadequate sensitisation towards these modern facilities. The finding of this study equally has implications for social work practice in Nigeria. Social workers have an important role to play in countering the practice of open defecation and also in disseminating the knowledge of public health challenges of open defecation while addressing factors that affect the knowledge of health challenges of open defecation. They are also needed in the formulation of social policies regarding open defecation to ensure that such policies are culturally sensitive for easy implementation.

Findings from this study revealed that a high percentage of respondents indicated that the practice of open defecation is a normal behaviour in their communities. Some noted that some people do not make certain to evacuate their filled toilets but opted to defecate in the open. All these factors are bad indicators. Thus, there is the need for professional social workers to educate the populace on the health hazards of open defecation. Also, social workers are to counsel and sensitize community members to change their perception of open defecation from being seen as a normal behaviour to unhealthy practice with dangerous health implications that should be collectively abandoned.

\section{Conclusion}

This study ascertained the knowledge of health challenges of open defecation among rural dwellers in south east Nigeria. It was estimated that about 2.4 billion people all over the world do not have access to basic sanitation facilities such as toilets or latrines. In Africa, about 233 million people still lack access to 
decent toilet facilities thereby defecate in open spaces; meanwhile the number of persons defecating in the open in Nigeria has increased from $24 \%$ of the total population in 1990 to $25.1 \%$ in 2015 . Open defecation is the leading cause of proliferation of acute excreta-related illnesses such as cholera, diarrhea, dysentery, hepatitis A, typhoid, polio, intestinal worms, schistosomiasis, and trachoma. Open defecation is also responsible for child stunting and mortality especially of children below five years. It is therefore a serious public health issue/challenge. From the study, it was found that majority of the respondents indicated that they defecate in the open spaces such as farmlands, streams, bushes etc. The study equally revealed that majority of the respondents have knowledge of health consequences of open defecation. However, several factors are responsible for defecating in open spaces. Such factors include lack of toilet facilities, lack of finance and education. Equally, attitudes of the rural dwellers prompt them to still defecate in the open spaces.

This study therefore provides implications for government and social work mediations. Health is one of the primary goals of governments across the globe; and is also, foremost in the African Union Agenda 2063. Therefore, as a matter of urgency, Nigerian governments should look at practices in other countries that have successfully implemented community-based approaches to total sanitation. For instance, India launched Clean India Mission known as Swachh Bharat Mission [SBM] in 2014 in order to achieve Open Defecation Free [ODF] status by 2019 through construction of household and community toilets as well as influencing behavioural change among rural dwellers (Alexander et al., 2016; United Nations in India, 2018). This programme has afforded many Indian households the opportunity to own private toilet facilities (Patwa and Pandit, 2018). Also, Bangladesh National Sanitation Campaign [BNSC] was launch in 2003 with the aim of ending open defecation by 2010. The introduction of BNSC provides a salient example of how government commitment and behaviour change methods can effectively reduce open defecation (Alexander et al., 2016). Thus, BNSC contributed in reducing open defecation in rural areas from $42 \%$ to $3 \%$ between 2003 and 2015 (Bangladesh Rural Advancement Committee [BRAC], 20I5; WHO/UNICEF, 20I5).

Social work as an empowering profession chiefly in the area of welfare services delivery should through advocacy help strengthen government efforts to eradicate the practice of open defecation by rural residents in South- east, Nigeria. Social workers also should take up educational programmes that enhance the knowledge of the rural populace about the implications of defecating in open spaces.
Finally, the important role of social workers as facilitators should be incorporated in relevant public health regulations. Through resource linkage/mobilization and advocacy they will sensitise households to provide their own private conveniences and thus ensure a safe environment in South-east Nigeria. For families and households who are desirous of owning a modern toilet facility but lack the resources to do so, we recommend a wellplanned conditional cash transfer scheme financed and administered by government alone or in collaboration with an NGO in the Water, Sanitation and Hygiene [WASH] sector.

\section{References}

Abramovsky, L., Augsburg, B. and Oteiza, F. (20/5). Sustainable Total Sanitation - Nigeria: Baseline Report [online]. Institute for Fiscal Studies in collaboration with In-depth Precision Consulting, Nigeria. Available at: https://www.ifs.org.uk/... /Abramovsky_et_al_Baseline\%20report\%20Nige ria\%20STS.... [Accessed Sep. 14, 2018]

Abubakar, I. R. (20I7). Access to Sanitation Facilities among Nigerian Households: Determinants and Sustainability Implications. Sustainability, [online] 9(4), pp. I-17. Available at: https://www.mdpi. com/207I-I050/9/4/547/pdf-vor [Accessed ]ul. 22, 20I7]

Adedini, S. A. (20I4). Neighbourhood Characteristics and Under-Five Mortality in Nigeria. African Population Studies, [online] 27(2), pp. 273-287. Available at: http://aps.journals.ac.za. [Accessed Oct. 30, 2018].

Ahmad, J. (20|4). How to Eliminate Open Defecation by 2030 [online]. Available at: http://www.how\% elimiate\%open\%defecation\%20\%30 [Accessed I5 Sep. 2018]

Akinson, B. (20/6). Open Defecation and Public Health. [online]. Available at: https://urbanpapar azzionline.com/2016/I I/22/open-defecation-and public-health. [Accessed $27 \mathrm{Dec}$. 2018]

Alexander, K., Allton, C., Felsman, C., Hahn, M., Okegbe, T., Palmer, D., Taglieri, J. and Thibe, M. (2016). Ending Open Defecation in India: Insights on Implementation and Behavior Change for Swachh Bharat Abhiyan. January 2016 Graduate Policy Workshop Report. Woodrow Wilson School of Public \& International Affairs. Princeton Univeristy.

Alhassan, A. and Anyarayor, B. K. (20/8). Determinants of Adoption of Open DefecationFree (ODF) Innovations: A Case Study of Nadowli-Kaleo District, Ghana. Journal of Development and Communication Studies, [online] 5(2), 54-69. Available at: 
https://www.ajol.info/index.php/jdcs/article/viewFi le/I74596/I63987. [Accessed 6 Feb. 2019].

Arku, F. S., Filson, G. C. and Shute, J. (2008). An Empirical Approach to the Study of Well-Being among Rural Men and Women in Ghana. Social Indicators Res. 88, pp. 365-387.

Ayitey, C. (2016). Open Defecation: The Greatest of African Nightmare. [online]. Available at: https://face2faceafrica.com/article/open-

defecation-greatest-nightmare-africa [Accessed 6 March 2018].

Banerjee, A. B., Pasha, M. A. M., Fatima, A. and Isaac, E. (20|3). A Study of Open Air Defecation Practice in Rural Nandivargam Village. International Journal of Bioassays, 2(07), pp. I05 I1054. I

Bhardwaj, A., Surana, A., Mithra, P., Singh, A., Panesar, S. and Chikkara, P. (20|3). A Community Based Cross Sectional Study on use of Sanitary Latrines in a Rural Setup in Maharashtra. Healthline, [online] I(4), pp. 68-93. Available at: https://www.researchgate.net/publication/283486 593_A_Community_based_cross_sectional_study on_use_of_sanitary_latrines_in_a_rural_setup_in Maharashtra. [Accessed 27 Dec. 2018].

BRĀC. (20I5). Open Defecation in Country has Been Reduced from $42 \%$ in 2003 to $3 \%$ in 2014 . [online]. Available at: http://wash.brac.net/news-amedia/ / 86-open-defecation-in-country-has-beenreduced-from-42-in-2003-to-3-in20I2. [Accessed 19 Apr. 2019].

Coffey, D., Gupta, A., Hathi, P., Khurana, N., Spears, D., Srivastav, N. and Vyas, S. (20I4). Revealed Preference for Open Defecation: Evidence from a New Survey in Rural North India. Economic \& Political Weekly EPW, 49(38), pp. 43-55.

Coffey, D., Gupta, A., Hathi, P., Spears, D., Srivastav, N. and Vyas, S. (2017). Understanding Open Defecation in Rural India: Untouchability, Pollution, and Latrine Pits. Economic \& Political Weekly, [online] 2(I), pp. 59-66. Available at: https://www.theigc.org/wp-content/uploads/.../ coffey-et-al-2016-working-paper.pdf. [Accessed 26 Jul. 2017]

Desai, R., McFarlane, C. and Graham, S. (20I5). The Politics of Open Defecation: Informality, Body, and Infrastructure in Mumbai. Antipode, 47(I), pp. 98-I 20.

Devkota, B., (20II). An Operational Study on 'Open Defecation Free (ODF) Situation' in Nepal. Kathmandu: Water Aid.

Federal Ministry of Water Resources (2016). Making Nigeria Open Defecation Free by 2025: A National Roadmap [online]. Abuja: Federal Republic of Nigeria. Available at: https://www.unicef.org
/nigeria/NATIONAL_ROAD_MAP_FOR_ELIMIN ATING_OP... [Accessed 6 Dec. $20 \overline{1}$ 7] $]$.

Galan, D. I., Kim, S. S. and Graham, J. P. (20/3). Exploring Changes in Open Defecation Prevalence in sub-Saharan Africa Based on National Level Indices. BMC Public Health, [online] I3(I), p. 527. Available at: https://bmcpublichealth.biomed central.com/articles //0.1/86//47/-2458-|3-527 [Accessed I4 Sep. 2018].

Geetha, J. and Kumar, S. S. (20I4). Open Defecation: Awareness \& Practices of Rural Districts of Tamil Nadu, India. International Journal of Scientific Research, [online] 3(5), pp. 537-538. Available at: https://www.researchgate.net/publication/269305 923. [Accessed I4 Sep. 20|8].

Gertler, P., Shah, M., Alzua, M. L., Cameron, L., Martinez, S. and Patil, S. (2015). How Does Health Promotion Work? Evidence from the Dirty Business of Eliminating Open Defecation. Working Paper Series. Center for Effective Global Action, University of California.

Giné-Garriga, R., Flores-Baquero, Ó. de Palencia, A. J. F. and Pérez-Foguet, A. (20/7). Monitoring Sanitation and Hygiene in the 2030 Agenda for Sustainable Development: A Review through the Lens of Human Rights. Science of the Total Environment, 580, pp. II 08-III9.

Hulland, K., Martin, N., Dreibelbis, R. and Winch, P. (20I5). What Factors Affect Sustained Adoption of Sanitation Interventions? A Systematic Review of Literature. International Initiative for Impact Evaluation, London.

International Association of School of Social Work [IASSW] \& International Federation of Social Work [IFSW] (20I4). Global definition of social work. Retrieved from http://ifsw.org/policies/definition-of-social-work/ [Accessed I8 Apr. 2019].

Kamara, J. K., Galukande, M., Maeda, F., Luboga, S. and Renzaho, A. M. N. (20/7). Understanding the Challenges of Improving Sanitation and Hygiene Outcomes in a Community Based Intervention: A Cross-Sectional Study in Rural Tanzania. International Journal of Environmental Research and Public Health, [online] 14(602), pp. I-I6. Available at: www.mdpi.com/journal/ijerph [Accessed I4 Sep. 2018].

Madumere, N. (2017). Public Enlightenment and Participation - A Major Contribution in Mitigating Climate Change. International Journal of Sustainable Built Environment, [online] 6, pp. 915. Available at: https://reader.elsevier.com/ reader/sd/pii/S22 I $26090|630|$ 480?token $=47 \mathrm{E} 66$ FC5DB65D4ED29F2CF40FC3CF38CA9IFD9AI 309D0D643BB2 I AAFC7E9E872A I I 74042FF350 
II6D665F6F4B86584BF. [Accessed I2 Apr. 2019]

Mara, D. (2017). The Elimination of Open Defecation and Its Adverse Health Effects: A Moral Imperative for Governments and Development Professionals. Journal of Water Sanitation and Hygiene for Development, [online] 7(I), pp. I-I2. Available at: https://iwaponline.com /washdev /.../The-elimination-of-open-defecation-and-itsadverse. [Accessed 2 Mar. 2018].

Mumbi, T. L. and Wilberforce, C. (20I7). An Assessment of Open Defecation Among Residents of Thika East Sub-County, Kiambu County, Kenya. International Journal of Medicine Research, [online] 2(3), pp. 9-20. Available at: www.medicinesjournal.com/download /98/2-I17-460.pdf [Accessed I4 Sep. 2018].

National Population Commission (2006). National Bureau of Statistics. Federal Republic of Nigeria.

Nigeria Data Portal (20I5). Distribution of Households by Type of Toilet Facility. [online]. Available at: http://nigeria.opendataforafrica.org/ thwsac/distribution-of-household-by-type-of-toil et-facility?region=Enugu. [Accessed 28 Jan. 2019].

Newman, A., Smets, S. and Kov, P. (20/4). Making Toilets More Affordable for the Poor Through Microfinance. Water and Sanitation Program, Washington, DC. World Bank

Ngwu, U. I. (2017). The Practice of Open Defecation in Rural Communities in Nigeria: A call for Social and Behaviour Change Communication Intervention. International Journal of Communication Research, [online] 7(3), pp. 20I206. Available at: https://www.ijcr. eu/articole 1373_08\%20Ukam\% 20lvi\%20NGWU.pdf [Accessed I4 Sep. 20I8]

Okafor, C. N. and Nwude, M. O. (2016). Sanitation and Hygiene Practices of Nigeria's Coastal Communities and Associated Socioeconomic Characteristics: Study of two Akwa lbom Communities. British Journal of Applied Science \& Technology, I4(2), pp. I-I 2.

Okechukwu, O. I., Okechukwu, A. A. and NoyeNortey, H. O. (20I2). Toilet Practices Among the Inhabitants of Kintampo District of Northern Ghana. Journal of Medicine and Medical Sciences, [online] 3(8), pp. 522-530. Available at: http://www.interesjournals.org/JMMS [Accessed 26 Jul. 2017].

Okullo, J. O., Moturi, W. N. and Ogendi, G. M. (2017). Open Defecation and Its Effects on the Bacteriological Quality of Drinking Water Sources in Isiolo County, Kenya. Environmental Health Insights, [online] II, pp. I-8. Available at: https://www.ncbi.nlm.nih.gov/pmc/articles/PMC5
637965/pdf/I0.II 77_II 786302 I7735539.pdf. [Accessed 5 Feb. 2019].

Patwa, J. and Pandit, N. (20/8). Open DefecationFree India by 2019: How Villages are Progressing? Indian Journal of Community Medicine, [online] 43(3), 246-247. Available at: https://www.ncbi. nlm.nih.gov/pmc/articles/PMC6I66505/ [Accessed I8 Apr. 2019]

Prasan, A. (2013). A Thought on World Toilet Day Open Defecation is a Problem of Dignity says the Humara Bachpan Campaign. [online] Available at: http://humarabachpan.wordpress.com/2013/I I/19 /world-toilet-day/ [Accessed I5 Dec. 2018].

Routray, P., Schmidt, W., Boisson, S., Clasen, T. and Jenkins, M. W. (20I5). Sociocultural and Behavioural Factors Constraining Latrine Adoption in Rural Coastal Odisha: An Exploratory Qualitative Study, BMC Public Health, [online] 15(2), pp. 2206 - 2213. Available at: https://www.ncbi.nlm .nih.gov/pubmed/26357958 [Accessed 26 Jul. 2017].

Rutaremwa, G. (20/2). Under-Five Mortality Differentials in Urban East Africa: A Study of Three Capital Cities. African Population Studies, [online] 26(I), pp. 30-49. Available at: http://aps.journals.ac.za. [Accessed 30 Oct. 20I8].

Sheafor, B. W. and Horejsi, C. R. (2006). Techniques and Guidelines for Social Work Practice. Boston: Pearson.

Solomon, B. B. (1976). Black empowerment: Social work in oppressed community. New York: Colombia University Press.

Spears, D., Ghosh, A. and Cumming, O. (20/3). Open Defecation and Childhood Stunting in India: An Ecological Analysis of New Data from $1 / 2$ Districts. PLoS One, 8(9), e73784.

Tarraf, A. (2016). Social and Behaviour Change Communication Insights and Strategy Case Study: Open Defecation in India. India: Walter Thompson.

This Day News (March I, 2016). The Dangers of Open Defecation. [online] Available at: http://www.file:

///C:/Users/dell/Desktop/FOLDER/Open\%20defe cation/THE\%20DANGERS\%20OF\%20OPEN\%2 ODEFECATION\%20_\%20THISDAYLIVE.htm [Accessed 6 Dec. 2017].

UNICEF (2018). UNICEF Convenes Key Players in Sanitation Markets in West Africa. UNICEF West and Central Africa. [online]. Available at: https://www.unicef.org/wca/press-releases/unicefconvenes-key-players-sanitation-markets-westafrica. [Accessed I 2 Apr. 2019]

UNICEF (20I5). Water, Sanitation and Hygiene. [online]. Available at: www.unicef.org. [Accessed I5 Jan. 20I8]. 
UNICEF/WHO (2017). Progress on Drinking Water, Sanitation and Hygiene: 2017 Update and SDG Baselines. Geneva: World Health Organization.

United Nations in India (2018). Ministry of Drinking Water and Sanitation and UNICEF announce the Mahatma Gandhi International Sanitation Convention, [online]. Available at: http://in.one. un.org/un-press-release/ministry-drinking-watersanitation-unicef-announce-mahatma-gandhi-inte rnational-sanitation-convention/ [Accessed 18 Apr. 2019].

Water and Sanitation Program (20/2). Nigeria: Economic Impacts of Poor Sanitation in Africa. [online]. Available at: <https://www.wsp.org/ sites/wsp.org/files/publications/WSP-ESI-Nigeriabrochure.pdf $>$ [Accessed 6 Jun. 20I7].

WHO (2016). Sanitation. [online]. Available at: http://www. who.int/mediacentre/factsheets /fs392 /en/ [6 Jun. 20I7].
WHO (2014). Burden of Disease and CostEffectiveness Estimates, WHO, Water Sanitation and Health (WASH), Geneva, Switzerland.

WHO/UNICEF (20I5). Progress on Sanitation and Drinking-water-2015 Update and MDG Assessment. Joint Monitoring Programme for Water Supply and Sanitation, World Health Organization, Geneva.

World Bank (2016). World Development Indicators 2016: Featuring the Sustainable Development Goals. Databank. Washington DC: World Bank Group.

Zastrow, C. (2004). Introduction to Social Work and Social Welfare: Empowering People. Belmont: Thompson Brooks/Cole. 